\title{
Evaluation of Microbial, Botanical, and Organic Treatments for Control of Peanut Seedling Diseases
}

\author{
S. J. Ruark and B. B. Shew, Department of Plant Pathology, North Carolina State University, Raleigh 27695
}

\begin{abstract}
Ruark, S. J., and Shew, B. B. 2010. Evaluation of microbial, botanical, and organic treatments for control of peanut seedling diseases. Plant Dis. 94:445-454.

Diseases affecting stand establishment are a major obstacle to organic production of peanut (Arachis hypogaea). Stand losses of 50\% or more are possible with untreated seed. Biological, botanical, and organic seed treatments or soil amendments were tested for efficacy against preand postemergence damping-off of peanut in greenhouse, microplot, and field plot trials. Seed of the lines Perry, GP-NC 343, and Bailey (tested as N03081T) were used in all trials. Commercial formulations of Bacillus subtilis (Kodiak), B. pumilus (Yield Shield), Trichoderma harzianum (T-22 PB and Plantshield HC), Muscodor albus, and Coniothyrium minitans (Contans); activated charcoal; two separate soil amendments of dried herbage of Monarda didyma cultivars; a commercial fungicide control (Vitavax PC); and an untreated control were tested in natural soil in the greenhouse. Vitavax PC and Kodiak were the only treatments that resulted in higher percent emergence and survival than in untreated seed. A separate greenhouse experiment was conducted in natural soil or natural soil infested with field isolates of Aspergillus niger. Seed were treated with Kodiak, copper hydroxide (Champion), Plantshield HC, Kodiak + Plantshield HC, Streptomyces griseoviridis (Mycostop), hot water, Vitavax PC, or were left untreated. Seedling emergence and survival was much lower in infested versus uninfested soil. Seed treatment with Kodiak increased percent emergence and survival compared to untreated seed, but was not as effective as Vitavax PC. Field microplot studies in 2007 and 2008 at Clayton, NC, evaluated four seed treatments on the peanut lines following small grain cover crops, soil amendment with $M$. albus, or no cover. Cover crops did not affect emergence or interact with seed treatments. In field studies in 2007 and 2008 at Lewiston, NC, the peanut lines were planted with M. albus infurrow, with Kodiak or T. harzianum seed treatments, or were untreated. In the 2007 trial, none of the treatments improved stands compared to the untreated check. In 2008, the highest stand counts were produced by seed treated with Kodiak. In both years, Bailey produced the greatest stand counts. A. niger was strongly associated with postemergence damping-off in the field. Regardless of peanut line, in many trials, Kodiak seed treatment increased emergence and survival over untreated seed.
\end{abstract}

There is a growing and unmet demand for organic peanuts (Arachis hypogaea L.) in the United States $(19,23)$. In 2005, about 4,600 ha of organic valencia-type peanuts were produced under irrigation in New Mexico and West Texas (USDAERS, http://www.ers.usda.gov/Data/Or ganic/Data/Othercrops.xls), where the arid climate is less favorable for pests such as weeds, insects, and diseases than in traditional production areas (19). However, there is increasing interest in producing organic runner- and virginia-type peanuts in traditional production areas in the southeastern United States. Pests are more difficult to control in this area, but progress has been made in foliar disease control (12). However, diseases affecting stand establishment remain a major ob-

Corresponding author: S. J. Ruark

E-mail: sjruark@gmail.com

Accepted for publication 18 December 2009.

doi:10.1094/PDIS-94-4-0445

(C) 2010 The American Phytopathological Society stacle to organic production in all growing areas.

In conventional practice, all commercial peanut seeds are treated with chemical fungicides, and growers are strongly discouraged from planting untreated seed (36). Planting untreated seed can result in stand losses of up to $50 \%$ (31). Peanut is susceptible to a variety of fungi causing pre- and postemergence damping-off, including Aspergillus niger Tiegh., Fusarium spp., Pythium spp., and Rhizoctonia solani Kühn (28).

A. niger causes Aspergillus crown rot of peanut. Seedlings are most susceptible during germination and the preemergence period (33). Infection is commonly observed on the cotyledon, hypocotyl, and crown (33). Symptoms of Aspergillus crown rot begin with rapid wilting, and diseased tissue is dark brown, turning lighter in color and shredding at later stages. Black spore masses are commonly observed on dead and dying plants (33). A. niger is a seedborne pathogen but also lives as a saprophyte in soil (33). Aspergillus crown rot has not been economically significant in the United States for decades because it is controlled by standard chemical seed treatment fungicides (33).

Breeders have not actively selected for resistance to A. niger in cultivar development. Partial resistance has been reported in cultivated peanut germplasm, and bunch types are thought to be more susceptible than runner types (33). Significant effort has been directed at breeding peanut for resistance to other major diseases (41), but it is not known if resistance to A. niger is associated with resistance to other soilborne pathogens.

Bacillus subtilis Cohn, a gram-positive, endospore-forming bacterium commonly found in soil, has been widely studied as a biocontrol organism. Turner and Backman (40) showed that B. subtilis AF 1 could consistently colonize peanut root systems. Peanut seed treated with $B$. subtilis had higher emergence than untreated seed when planted at low temperatures; however, no effect on root or seedling diseases was observed in field studies (40). B. subtilis AF 1 applied to peanut seed resulted in seedlings with increased emergence rates, vigor, fresh and dry weight, and root and shoot length compared to untreated seed or seed infected with A. niger (34). B. subtilis GB03, formulated as Kodiak (Bayer CropScience, Research Triangle Park, NC), was highly viable on cotton and bean seedlings when applied prior to seed delivery and planting (15). Kodiak applied in combination with standard chemical fungicides on cotton and snap bean increased seedling stands over untreated seed (4). On other hosts, Kodiak controls fungi, including $R$. solani, Fusarium spp., and Aspergillus spp., that attack peanut roots (18).

Trichoderma harzianum Rifai, has been reported to have some efficacy against $A$. niger as a peanut seed treatment (30). Against other peanut seedling diseases, it was more effective when applied as a preplant soil amendment (14). Application of $T$. harzianum to seeds of cotton or snap bean did not increase seedling stands over untreated seed (5). Coniothyrium minitans Campbell is a parasite of sclerotia of Sclerotinia spp., including Sclerotinia minor Jagger, a pathogen of peanut (10). It is compatible with pesticides used in conventional peanut production (32), but has not been studied on peanut in combination with other biocontrol agents. Seed treatment with copper hydroxide (39) and immersion in hot water also have been used to improve emergence or survival of peanut seed $(1,17)$. 
Several organisms have activity against soilborne pathogens that can infect peanut but have not been tested on peanut. The fungus Muscodor albus Worapong et al. produces volatile organic compounds (38) and has been used as a preplant "mycofumigant" to enhance stand establishment in sugar beet and eggplant (37). Bacillus pumilus Meyer \& Gottheil GB34, marketed as Yield Shield (Bayer CropScience), has reduced disease incidence and severity of $R$. solani on soybean (27). The plant genus Monarda contains essential oils with antifungal properties $(16,21)$. Addition of dried herbages of Monarda didyma $\mathrm{L}$. to planting media suppresses activity of Pythium myriotylum, $R$. solani, and other plant pathogens $(13,20,21)$. Streptomyces griseoviridis Anderson et al., the biological agent in the product Mycostop (Verdera Oy, Espoo, Finland), has activity against Fusarium spp., Pythium spp., and Rhizoctonia spp. (29).

This research was conducted to investigate biological or other organically acceptable alternatives to conventional fungicides for the promotion of peanut stand establishment and seedling health, and their integration with other production practices. Greenhouse trials were conducted to examine a wide range of available diseasecontrol materials, and field trials were conducted to determine the suitability of selected products for seedling disease control under organic production conditions. Cover crops commonly are used to suppress weed populations in organic production systems, but in conventional production, good stand establishment sometimes is difficult when peanuts are planted into heavy residues (D. L. Jordan, personal communication). Microplot trials were planted to investigate the efficacy of selected materials when used after commonly grown cover crops. Three peanut lines with partial resistance to different peanut diseases were used in all trials to evaluate their potential for use by organic producers.

Table 1. Source and germination test results for peanut seed used in greenhouse, microplot, and field experiments

\begin{tabular}{|c|c|c|c|c|}
\hline Year & Experiment & Seed line & Source & $\begin{array}{c}\text { Germination } \\
(\%)\end{array}$ \\
\hline \multirow[t]{6}{*}{2007} & \multirow[t]{3}{*}{ Greenhouse natural $^{\mathrm{y}}$, run 1} & Perry & Breeder & 94 \\
\hline & & Bailey & Breeder & 96 \\
\hline & & GP-NC 343 & Breeder & 68 \\
\hline & \multirow[t]{3}{*}{ Microplots; field } & Perry & Commercial & 62 \\
\hline & & Bailey & Breeder & 83 \\
\hline & & GP-NC 343 & $\begin{array}{l}\text { Research, } \\
\text { commercially shelled }\end{array}$ & 41 \\
\hline \multirow[t]{6}{*}{2008} & \multirow{3}{*}{$\begin{array}{l}\text { Greenhouse natural, run 2; } \\
\text { greenhouse infested }^{\mathrm{z}} \text {, runs } 1 \\
\text { and } 2 ; \text { microplots }\end{array}$} & Perry & Research & 69 \\
\hline & & Bailey & Research & 82 \\
\hline & & GP-NC 343 & Research & 78 \\
\hline & \multirow{3}{*}{$\begin{array}{l}\text { Field; greenhouse Kodiak dose } \\
\text { (Perry only) }\end{array}$} & Perry & Commercial & 36 \\
\hline & & Bailey & Research & 82 \\
\hline & & GP-NC 343 & Research & 78 \\
\hline
\end{tabular}

y Trial conducted in natural field soil.

${ }^{\mathrm{z}}$ Trial conducted in natural field soil and in natural soil infested by addition of sorghum seed colonized by Aspergillus niger.

\section{MATERIALS AND METHODS}

Eight seed treatments, two in-furrow treatments, and two soil amendments were evaluated in three greenhouse experiments, one in natural soil, one in infested natural soil, and one comparing doses of Kodiak; a microplot experiment; and a field experiment. The microplot and field experiments were conducted twice, in 2007 and 2008, and all greenhouse experiments were repeated. Three virginia-type peanut lines were used in all experiments, except the Kodiak dose experiment. The cultivar Perry has moderate resistance to the soilborne pathogens Cylindrocladium parasiticum Crous, M.J. Wingf. \& Alfenas and Sclerotinia minor (22); the germplasm line GP-NC 343 has moderate to high resistance to leaf spot pathogens and insects (11); and the advanced breeding line N03081T has multiple disease resistance and was released as the cultivar Bailey in 2008 (T. G. Isleib, personal communication).

Seeds used in these studies were purchased commercially, harvested from research plots, or obtained from the peanut breeding program of T. G. Isleib, North Carolina State University (Table 1). Seeds of Perry, Bailey, and GP-NC 343 were obtained from T. G. Isleib for use in the first run of the greenhouse experiment with natural soil. Breeder seed was produced under irrigation and was carefully handled from harvest to storage, minimizing many of the injuries that occur during commercial production. Seeds obtained from breeder and research sources were hand sorted to remove seeds that were shriveled, broken, or missing testas and counted prior to planting in greenhouse and microplot experiments. Seed planted in the field was not sorted prior to use. Perry seeds planted in microplots in 2007, field experiments in 2007 and 2008, and the Kodiak dose experiment were purchased from a commercial source (Severn Peanut Company, Severn, NC). Bailey seeds planted in the microplots and field in 2007 were obtained from T. G. Isleib. The GP-NC 343 seeds used in the 2007 experiments were obtained from research plots grown in 2006 and were shelled by a commercial sheller. In the second run of the natural soil greenhouse experiment, both runs of the infested soil experiment, and the microplot experiment in 2008, all peanut lines were grown in 2007 in research plots at the Peanut Belt Research Station in Lewiston, NC. In the microplot and field experiments in 2008, Bailey and GP-NC 343 seeds were obtained from this same source. Seeds from each peanut line were handled uniformly, including drying conditions, shelling with a mechanical sheller, hand sorting, and cold storage.

Germination of individual seed lots. Standard industry tests for germination and seedling development were conducted on seed used in all experiments (2). Untreated seeds were placed in sterile sand in $51 \times$ $36 \times 10 \mathrm{~cm}$ flats. All tests used 50 seeds/flat, except for Perry seed in the first run of the greenhouse experiment in natural soil, where 32 seeds/flat were used. Flats were placed in a greenhouse and watered twice daily. Greenhouse temperature varied with the season in which the tests were conducted and ranged from 25.5 to $32.2^{\circ} \mathrm{C}$ across all tests. Germinated seeds were counted 7 days after planting, and normal seedling development (the number of seeds that developed roots and cotyledons absent of signs and symptoms of infection [2]) was evaluated at 10 days after planting.

Greenhouse evaluation of seedling disease control in natural soil. Soil used in all greenhouse experiments was collected from a field at the Peanut Belt Research Station in Lewiston, NC. The field was undergoing transition to organic production and was the same field used in the field trials described below. The soil was a Pantego loam (Fine-loamy, siliceous, semiactive, thermic Umbric Paleaquults). Soil was screened and stored in an open container in the greenhouse. All greenhouse experiments were conducted in $\mathrm{Su}$ per Cell Cone-tainers $(21 \times 3.8 \mathrm{~cm}$ diameter, Ray Leach Cone-tainer, Canby, OR). Each Cone-tainer contained approximately $150 \mathrm{~cm}^{3}$ of soil. Seeds were planted singly in Cone-tainers in experimental units of 21 Cone-tainers per treatment. One day prior to planting, seeds to be treated were coated with test materials by placing the seeds and treatments in a plastic bag and agitating the bag until the seeds were coated. In the two runs of the experiment, average greenhouse temperature was $28 / 17^{\circ} \mathrm{C}$ day/night. In the first run, plants were grown in the greenhouse with overhead misting applied for $1 \mathrm{~min}$ every $4 \mathrm{~h}$. In the second run, plants were grown on an open bench and watered twice a day by hand.

Two runs were conducted in natural soil using a total of nine seed treatments, soil 
surface applications, or soil amendments. The five seed treatments tested included: activated carbon $(4.1 \mathrm{~g} / \mathrm{kg}$ seed, activated charcoal, Fisher Science Education, Rochester, NY), Bacillus pumilus GB34 (9.7 $\mathrm{g} / \mathrm{kg}$ seed, Yield Shield Concentrate Biological Fungicide, Bayer CropScience), Bacillus subtilis GB03 (10 g/kg seed, Kodiak Concentrate Biological Fungicide, Bayer CropScience), Trichoderma harzianum KRL-AG2 (1.1 g/kg seed, T-22 Planter Box Biological Fungicide, Bioworks Inc., Geneva, NY), or a standard commercial seed treatment mixture of captan, carboxin, and pentachloronitrobenzene $(2.2 \mathrm{~g} / \mathrm{kg}$ seed, Vitavax PC Flowable Fungicide, Bayer CropScience). Two additional treatments that were formulated to be applied in-furrow in the field were applied to the soil surface at the time of planting. Seeds in these treatments were placed on the treated soil and covered with approximately $5 \mathrm{~cm}$ of unamended soil. The treatments included Muscodor albus QST 20799 (1.4 g/liter soil, Agraquest Inc., Davis, CA) and Coniothyrium minitans CON/M/91-08 (3 mg/cone, Contans WG, Sylvan Bioproducts Inc., Kittanning, PA). Contans WG was applied to soil in combination with seeds treated with T-22 Planter Box. Two soil amendments of herbage from the Monarda didyma cultivars Mohawk and Mahogany (K. D. Gwinn, University of Tennessee, Knoxville) were tested. Dried leaves and stems harvested in 2005 were ground to pass through a 5-mm mesh and stored in glass jars before use. The herbage was mixed by hand into the natural field soil to $6 \%$ $\mathrm{vol} / \mathrm{vol}$, and the amended soil was used to fill the Cone-tainers. Untreated seeds also were planted in the amended soils and in unamended soil as controls. In the second run, an alternate formulation of $T$. harzianum KRL-AG2 (1.1 g/kg, Plantshield $\mathrm{HC}$, Bioworks) was used alone or in combination with Contans WG as described above. In both runs, emergence was evaluated weekly for 4 weeks starting 2 weeks after planting. Emergence and survival, defined as those plants with shoots that were apparently healthy, was evaluated at 5 weeks after planting. Diseased seedlings were counted, removed, and their lesions excised, surface-sterilized, and plated on potato dextrose agar, alkaline water agar, and PAR Pythium medium as described by Kannwischer and Mitchell (25) and modified by Shew (35) minus hymexazol.

Greenhouse evaluation of seedling disease control in soil infested with $A$. niger. Two runs of an infestation experiment were conducted on Perry, GP-NC 343, and Bailey. A. niger was isolated from diseased plants during the 2007 field experiment described below and maintained on potato dextrose agar. A 30-ml spore suspension was added to 1-liter flasks containing twice-autoclaved sorghum seed and allowed to grow for 13 days at $30^{\circ} \mathrm{C}$, at which time the fungus was profusely sporulating (26). Cone-tainers were filled to within 2.5 to $5 \mathrm{~cm}$ of the top with natural field soil, and $2.5 \mathrm{~cm}^{3}$ of colonized sorghum seed was added at planting. Peanut seeds were placed directly on the colonized sorghum and were covered with natural soil. The experiment was conducted as a split-plot experimental design with infestation treatments (with or without colonized sorghum) as whole plots and seed treatment by cultivar treatments as subplots. Treatments were seeds treated as described above with Kodiak, Plantshield HC, Kodiak + Plantshield HC, Vitavax PC, copper hydroxide $(3.9 \mathrm{~g} / \mathrm{kg}$ seed Champion Wettable Powder [Champion WP], Nufarm Americas Inc., Burr Ridge, IL), deionized hot water (immersion at $50^{\circ} \mathrm{C}$ for $15 \mathrm{~min}$ ), Streptomyces griseoviridis K61 $(5.0 \mathrm{~g} / \mathrm{kg}$ seed, Mycostop Mix, Verdera Oy), or untreated seeds. Seedling emergence was monitored for 4 weeks beginning 2 weeks after planting, and survival was evaluated 5 weeks after planting. In these experiments, average greenhouse temperature was $28 / 22^{\circ} \mathrm{C}$ day/night. Plants were grown on an open bench and watered twice a day by hand.

Effects of Kodiak rate on seedling emergence and survival in the greenhouse. Two runs of a dose-response experiment were conducted in the greenhouse using six rates of Kodiak on Perry seed. Experiments were conducted in natural soil in Cone-tainers as previously described. The experiment was conducted as a randomized complete block design with four replications of 21 Cone-tainers as the experimental unit. For the highest rate treatment, Kodiak was applied at $10 \mathrm{~g} / \mathrm{kg}$ seed. For the remaining treatments, Kodiak was then diluted using the inert ingredients of the formulation as provided by Bayer CropScience. The dilution series consisted of treatments at $5 \mathrm{~g} / \mathrm{kg}$ seed, $1.25 \mathrm{~g} / \mathrm{kg}$ seed, $0.31 \mathrm{~g} / \mathrm{kg}$ seed, $0.08 \mathrm{~g} / \mathrm{kg}$ seed, and a treatment with inert ingredients only. Seedling emergence was monitored for 4 weeks beginning 2 weeks after planting, and survival was evaluated 5 weeks after planting. In this experiment, average greenhouse temperature was $28 / 22^{\circ} \mathrm{C}$ day/night. Plants were grown on an open bench and watered twice a day by hand.

Evaluation of seedling disease control in microplots. Cylindrical microplots (76 $\mathrm{cm}$ diameter with fiberglass barriers [3]) at the Central Crops Research Station in Clayton, NC were planted with wheat (Triticum aestivum L. cv. NC Neuse), oat (Avena sativa $\mathrm{L}$. cv. Rodgers), or triticale ( $\times$ Triticosecale spp. cv. Arcia) on 28 November 2006 and 2 November 2007. The soil was a Norfolk loamy sand (Fineloamy, kaolinitic, thermic Typic Kandiudults). Plots were tilled by hand to a depth of 25 to $30 \mathrm{~cm}$, and fertilizer was added at planting (12N-6P-24K with $3 \%$ sulfur, Camp's Chemical Corporation,
Roxboro, NC). In 2006, the microplots had been fallow for 1 year, but prior to that had been planted to tobacco for 6 years. Plots remained fallow after peanut in 2007 , and small grain cover crops were planted in the same plots as the previous year. The cover crops were cut while still green on 26 April 2007 and 16 April 2008, and the residues were allowed to dry in the field until planting. Residues of the same species were combined within a replicate and distributed equally between plots. At planting, the cover crops were turned into the soil, and the rye grains colonized with $M$. albus were raked into the top 1 to $2 \mathrm{~cm}$ of the soil surface $(102 \mathrm{~kg} / \mathrm{ha}$ in 2007 and 50 $\mathrm{kg} / \mathrm{ha}$ in 2008). Treatments were arranged in a split-plot design with four replicates. The three cover crops, no cover crop, or no cover crop + soil amendment with $M$. albus treatments in factorial combination with five seed treatments were assigned as whole plot units. Subplots were generated by dividing the plot into thirds using plastic plant bed edging with each third containing 10 seeds of one of the three peanut lines Perry, GP-NC 343, and Bailey.

Peanut seeds were planted by hand on 22 May 2007 and 20 May 2008 approximately $5 \mathrm{~cm}$ deep and $5 \mathrm{~cm}$ apart. Prior to planting, seeds were treated with activated carbon $(2.5 \mathrm{~g} / \mathrm{kg}$ seed), Kodiak $(2.5 \mathrm{~g} / \mathrm{kg}$ seed), or Vitavax PC $(2.5 \mathrm{~g} / \mathrm{kg}$ seed $)$, or were left untreated. T. harzianum formulated as T-22 Planter Box (1.2 g/kg seed) was applied as a seed treatment in 2007; in 2008, the Plantshield HC (1.2 g/kg seed) formulation was used. Seed treatments were applied to the seeds as previously described. In 2007, plots were irrigated once every 3 days. Irrigation was not necessary in 2008. In both years, plots were weeded weekly by hand. Emerged and surviving peanut plants were counted once a week for 4 weeks starting 7 days after planting in 2007 and 14 days after planting in 2008. The incidence of postemergence damping-off was evaluated.

Evaluation of seedling disease control in the field. A field test was planted at the Peanut Belt Research Station in Lewiston, NC on 21 May 2007 and 14 May 2008. The soil was a Pantego loam as described above. The field had been planted to soybean and maintained without chemical inputs in 2006. Tillage was conventional in both years, and peanuts were planted with a two-row tractor-mounted inclined-plate planter. Seeds were planted in $9.1-\mathrm{m} \times 2$ row plots at a rate of 10 to 13 per meter. Row spacing was $90 \mathrm{~cm}$. Standard organic production practices were followed throughout the experiment. In 2008, the plots were evenly split across land that had been fallow the previous year and land that had been planted to sorghum and were blocked accordingly. Seeds of Perry, GPNC 343, and Bailey were treated with Kodiak ( $2.5 \mathrm{~g} / \mathrm{kg}$ seed), T. harzianum formulated as T-22 Planter Box $(1.2 \mathrm{~g} / \mathrm{kg}$ 
seed) in 2007 or as Plantshield HC (1.2 $\mathrm{g} / \mathrm{kg}$ seed) in 2008 , or left untreated. Seed treatment was applied as previously described. The fourth treatment was an infurrow application of $M$. albus at a rate of $66 \mathrm{~kg}$ of rye seed inoculum/ha in 2007, and $45 \mathrm{~kg} / \mathrm{ha}$ in 2008 . There were four replications in a randomized complete block design. Stand counts (number of plants visible above the soil surface) were taken four times at weekly intervals beginning 2 weeks after planting. Diseased plants were counted and examined for signs and symptoms of common seedling diseases. Field plots were disked under following the fifth week of stand counts.

Data analysis. In all experiments, mean percent emergence and survival increased over 5 weeks, and plants did not die faster than they emerged. Therefore, data from the final week are presented as representative of the entire process. For the greenhouse experiments, seedling emergence and survival were converted from plant counts to a percentage based on 21 seeds per experimental unit. All analyses were conducted using SAS v. 8.0 (SAS Institute, Cary, NC). Percent emergence and survival data from counted seedlings in both greenhouse experiments were combined for analysis, and interactions with run were evaluated using PROC MIXED with type 3 estimation and Satterthwaite degrees of freedom methods, with peanut line and treatment as fixed effects and replicates and runs as random. Because treatments interacted with run, data from counted seedlings were sorted by run, and analysis of variance (ANOVA) was performed to determine the significance of experimental treatment effects and their interactions using PROC ANOVA. For microplot and field experiments, emergence and survival data from counted seedlings in 2007 and 2008 were combined for analysis and interactions with year were evaluated using PROC MIXED as described above, with peanut line and treatment as fixed effects and replicates and years as random. For the microplot experiment, due to interaction between years, data from counted seedlings were sorted by year for further analysis and presentation. ANOVA was per- formed to determine the significance of cover, seed treatments, and peanut line using PROC GLM. Seedling emergence and survival was expressed as a percentage based on 10 seeds per experimental unit. In the field experiment, significance of treatment effects on stand counts was evaluated using PROC ANOVA. In all experiments, differences in mean emergence and survival were evaluated using the WallerDuncan $k$-ratio test with $k=100$. For the dose response experiment, data from both runs were combined and analyzed using PROC MIXED as described previously, with Kodiak rate as a fixed effect and replicates and runs as random.

Data also were adjusted to evaluate the number of emerged and surviving plants with respect to the maximum percent germination of each seed lot from the germination tests. For the greenhouse and microplot experiments, the percentage of emerged, surviving plants was multiplied by the mean percent germination for their respective seed lot from the germination tests. In the field experiment, we assumed that 212 seeds were planted per plot ([3.5 seeds $/ 0.3 \mathrm{~cm}] \times 9.1 \mathrm{~m} \times 2$ rows). The projected maximum stand size was determined by multiplying 212 by the maximum percent germination for the corresponding seed lots from the germination tests. The number of emerged, surviving plants observed in the field were divided by the projected maximum stand to obtain the mean percentage of emerged, surviving seedlings. ANOVA and analysis of run and year interactions in the adjusted data were conducted as previously described.

\section{RESULTS}

Germination tests of individual seed lots. Germination varied depending on seed source and peanut line. In general, the highest percent germination was observed in seed from research sources and breeder's seed compared to commercially purchased seed (Table 1). Germination of Perry seed was highly variable, depending on source. Perry seed from breeder and research sources had higher percent germination than that from commercial

Table 2. $P$ values from analyses of variance using PROC MIXED for effects of peanut line, seed treatment, run, and replicate on emergence and survival of peanut seed 5 weeks after planting in natural soil in the greenhouse

\begin{tabular}{lccc}
\hline Source & df & Counted $^{\mathbf{y}} \boldsymbol{P}>\boldsymbol{F}$ & Adjusted $^{\mathbf{z}} \boldsymbol{P}>\boldsymbol{F}$ \\
\hline Peanut line (PL) & 2 & 0.5043 & 0.9767 \\
Treatment (T) & 9 & 0.0466 & 0.0678 \\
PL $\times$ T & 18 & 0.4908 & 0.3305 \\
Run (RN) & 1 & 0.0086 & 0.0696 \\
Replicate (run) & 4 & 0.0426 & 0.0171 \\
RN $\times$ PL & 2 & 0.0008 & 0.0001 \\
RN $\times$ T & 9 & 0.0003 & 0.0008 \\
RN $\times$ PL $\times$ T & 18 & 0.2344 & 0.0166 \\
\hline
\end{tabular}

${ }^{y}$ Results from analyses of percent emergence and survival of counted seedlings.

${ }^{z}$ Results from analyses of percent emergence and survival using data adjusted to account for maximum percent germination from germination tests. sources. Seed of Bailey used in all experiments had high germination (Table 1). Germination was low in the seed of GPNC 343 used in the first run of the greenhouse experiment in natural soil and microplot and field experiments in 2007 , and GP-NC 343 had the lowest germination of all peanut lines used within the same experiment. Fungi observed on seed in germination tests included A. niger, Rhizopus spp., and Fusarium spp. No association between a particular fungus and seedling disease was observed.

Greenhouse evaluation of seedling disease control in natural soil. Run interactions with peanut line and treatment were significant for emergence and survival based on percentages of counted seedlings (Table 2); therefore, results were analyzed and presented by run (Figs. 1 and $2)$. Peanut lines differed in emergence and survival in the first run $(P<0.0001)$, but not the second $(P=0.5551$; Fig. 1$)$. In the first run, the highest percent emergence and survival at 5 weeks was observed in Bailey (N03081T), while emergence was lowest in GP-NC 343 (Fig. 1). In both runs, seed treatment affected emergence and survival $(P<0.0001$; Fig. 2$)$. Vitavax $\mathrm{PC}$ and Kodiak produced higher percent emergence and survival at 5 weeks than all other treatments in both runs (Fig. 2). Response to other treatments varied depending on run, but none increased percent emergence and survival compared to untreated seed. Fusarium spp., Pythium spp., Rhizoctonia spp., Rhizopus spp., Trichoderma spp., and A. niger were the fungi most commonly observed from plated lesions.

There was a significant interaction between run, peanut line, and seed treatment for the adjusted percentage of emerged, surviving seedlings (Table 2). For the adjusted data in the first run, Bailey and GPNC 343 had higher percent emergence and survival, 91 and $98 \%$, respectively, than Perry, $79 \%$, while in the second run Perry had higher percent emergence and survival $(66 \%)$ than the other two peanut lines (45\% for GP-NC 343 and 47\% for Bailey). There was a significant interaction between peanut line and seed treatment in the second run $(P=0.0014$; ANOVA by run not shown). Kodiak treatments had the highest percent emergence and survival in all peanut lines, but were not different from Vitavax PC in Perry and Bailey (data not shown). None of the other treatments produced a higher percentage of emerged and surviving plants than untreated seed in any peanut line based on adjusted data.

Greenhouse evaluation of seedling disease control in soil infested with $A$. niger. There was a significant interaction of run by infestation treatment by seed treatment for percentages obtained from counted seedlings (Table 3 ), so data were analyzed individually for each run. In both infestation runs, seed treatment perform- 
ance varied depending on infestation treatment $(P<0.0001$; Fig. 3$)$. There was a lower percentage of emerged, surviving plants observed in artificially infested soil (Fig. 3A) compared to natural soil (Fig. $3 \mathrm{~B})$ in both runs.

In artificially infested soil, the highest percent emergence and survival was observed in both runs in seed treated with Vitavax PC (Fig. 3A). Seed treated with Kodiak, Kodiak + Plantshield HC, and Champion WP in the first run produced a higher percentage of emerged, surviving plants than were obtained from untreated seed, although emergence was less than in the Vitavax PC control. Plantshield HC, Mycostop Mix, and the deionized hot water treatment were not different from untreated. In the second run, treatment with Kodiak produced a higher percentage of surviving plants than the untreated check, but emergence was significantly less than in the Vitavax PC control (Fig. 3A). None of the other treatments increased emergence over the untreated control. Run interactions were still significant for adjusted data (Table 3). ANOVA results and relative ranking of treatments was the same as in the unadjusted data (data not shown).

In unamended natural soil in both runs, the percentage of emerged, surviving plants was greatest from seed treated with Vitavax PC. In the first run, emergence and survival of seed treated with Champion WP was not different from the Vitavax PC treatment (Fig. 3B). Kodiak and Kodiak + Plantshield HC produced a higher percentage of surviving plants than untreated seed, and treatment with Mycostop or hot water resulted in a lower percent emergence and survival than untreated in both runs. ANOVA results and relative rankings of treatment differences did not change with analysis of adjusted data (Table 3; data not shown).

In unamended natural soil, emergence and survival differed among lines in both runs $(P<0.0001$; Fig. 4). Perry and Bailey produced a higher percentage of emerged,

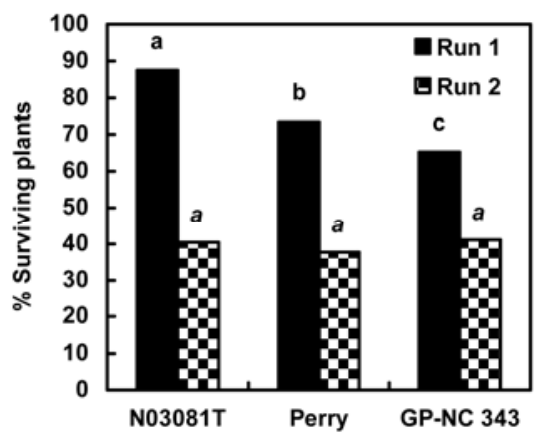

Fig. 1. Mean percent emergence and survival of peanut lines GP-NC 343, Bailey (N03081T), and Perry 5 weeks after planting in the greenhouse in natural soil. Means are averaged across 10 seed treatments. Bars with the same letter within a run are not different based on WallerDuncan procedure with $k$-ratio $=100$. surviving seedlings than GP-NC 343 in both runs (Fig. 4). Analysis of adjusted data ranked Perry with the highest emergence and survival in both runs (93\% in run one and $75 \%$ in run two) relative to Bailey ( $78 \%$ in run one and $59 \%$ in run two) and GP-NC 343 (68\% in run one and $50 \%$ in run two).

Effects of Kodiak rate on seedling emergence and survival in the greenhouse. Kodiak rate significantly affected emergence and survival of plants in the greenhouse. Higher percentages of emergence and survival were observed with higher rates of Kodiak (Fig. 5).

Evaluation of seedling disease control in microplots. In 2007, the average daily temperatures at the Clayton site for May and June were 20 and $24.2^{\circ} \mathrm{C}$; in 2008 , the average temperatures for May and June were 19.1 and $26.3^{\circ} \mathrm{C}$. In 2007, there were $2.3 \mathrm{~cm}$ of rain in May and $6.5 \mathrm{~cm}$ in June; while in 2008 there were $5.9 \mathrm{~cm}$ in May and $6.3 \mathrm{~cm}$ in June. There was a significant

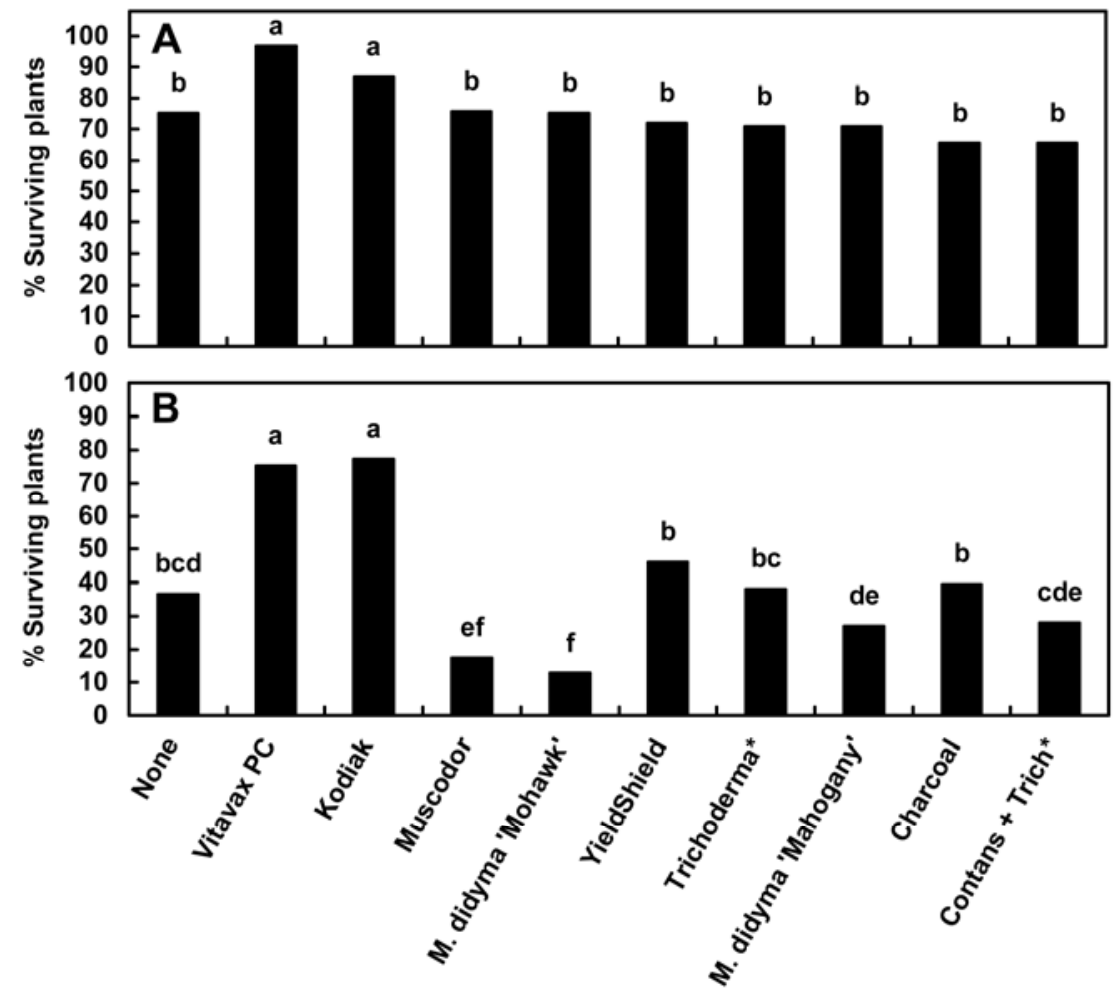

Fig. 2. Mean percent emergence and survival of peanut seedlings 5 weeks after planting in the greenhouse in natural soil in $\mathbf{A}$, run 1 and $\mathbf{B}$, run 2. Means are averaged across three peanut lines. Bars with the same letter within a run are not different based on Waller-Duncan procedure with $k$-ratio $=100$. Asterisks indicate differences in formulation of Trichoderma harzianum. In run 1, T-22 Planter Box was used; in run 2, Plantshield HC.

Table 3. $P$ values from analyses of variance using PROC MIXED for effects of inoculum, peanut line, seed treatment, run, and replicate for emergence and survival of peanut seed 5 weeks after planting in soil artificially infested with Aspergillus niger

\begin{tabular}{lccc}
\hline Source & df & Counted $^{\mathbf{P}} \boldsymbol{>} \boldsymbol{F}$ & Adjusted $^{\mathbf{z}} \boldsymbol{P}>\boldsymbol{F}$ \\
\hline Inoculum (I) & 1 & 0.0669 & 0.0691 \\
Peanut line (PL) & 2 & 0.0081 & 0.0328 \\
Treatment (T) & 7 & 0.0001 & 0.0001 \\
PL $\times$ T & 14 & 0.2168 & 0.0347 \\
$\mathrm{I} \times$ PL & 2 & 0.1540 & 0.1191 \\
$\mathrm{I} \times \mathrm{T}$ & 7 & 0.0280 & 0.0272 \\
$\mathrm{I} \times \mathrm{PL} \times \mathrm{T}$ & 14 & 0.2054 & 0.0522 \\
Run $(\mathrm{RN})$ & 1 & 0.9747 & 0.8743 \\
Replicate (run) & 4 & 0.1139 & 0.1501 \\
RN $\times$ PL & 2 & 0.9318 & 0.6028 \\
RN $\times$ T & 7 & 0.9986 & 0.9988 \\
RN $\times$ I & 1 & 0.3496 & 0.3421 \\
RN $\times$ I $\times$ PL & 2 & 0.0907 & 0.0439 \\
RN $\times$ I $\times$ T & 7 & 0.0001 & 0.0001 \\
RN $\times$ PL $\times$ T & 14 & 0.0790 & 0.0647 \\
RN $\times$ I $\times$ PL $\times$ T & 14 & 0.9525 & 0.9509 \\
\hline
\end{tabular}

${ }^{\mathrm{y}}$ Results from analyses of percent emergence and survival of counted seedlings.

${ }^{z}$ Results from analyses of percent emergence and survival using data adjusted to account for maximum percent germination from germination tests. 
interaction of year by peanut line by seed treatment $(P=0.0013$; Table 4$)$ for percent emergence and survival using seedling counts, so these effects were analyzed separately for each year (Table 5).

In both years, there was no difference in the percentage of surviving plants produced following any small grain cover crop or the no cover control (Table 5). In 2007, there was a lower percentage of emerged and surviving plants in GP-NC 343 plots treated with $M$. albus; however, in 2008, M. albus reduced percent emergence and survival only in Bailey (Table 5). Microplot results did not change for the adjusted data (Table 4).

In both years, the highest percentage of emerged, surviving plants for Perry was from seeds treated with Vitavax PC (Fig. 6A). For Bailey and GP-NC 343, none of the seed treatments in 2007 increased the percentage of emerged, surviving plants over untreated seed, and treatment of GPNC 343 with T-22 Planter Box reduced stands compared to untreated seed (Fig. 6B and C). In 2008, seed of these two treated with Vitavax PC produced a higher percentage of surviving plants than the un- treated check. In 2007, postemergence damping-off was observed in only two plants; however, in 2008, postemergence damping-off was observed in 105 plants, 97 with A. niger infections.

Evaluation of seedling disease control in the field. At the Lewiston site in 2007, the average daily temperatures for May and June were 19.3 and $24.1{ }^{\circ} \mathrm{C}$, while in 2008 the average temperatures for these months were 19.0 and $26.3^{\circ} \mathrm{C}$. Precipitation for 2007 was $5.8 \mathrm{~cm}$ in April, $5.6 \mathrm{~cm}$ in May, and $7.4 \mathrm{~cm}$ in June, and in 2008 was $10.1 \mathrm{~cm}$ in April, $8.2 \mathrm{~cm}$ in May, and $4.8 \mathrm{~cm}$ in June. In both years, there were differences in stand counts at 5 weeks after planting depending on peanut line $(P<$ 0.001; Table 6). Germination increased over time for all lines, and the highest stand counts at 5 weeks were produced by Bailey (N03081T; Fig. 7). In 2007, GP-NC 343 produced the lowest stand counts, whereas in 2008 Perry produced the lowest. In 2007, none of the treatments resulted in greater stand counts than untreated seed, and seed treated with $\mathrm{T}-22$ Planter Box produced significantly lower stand counts than untreated (Fig. 8). In
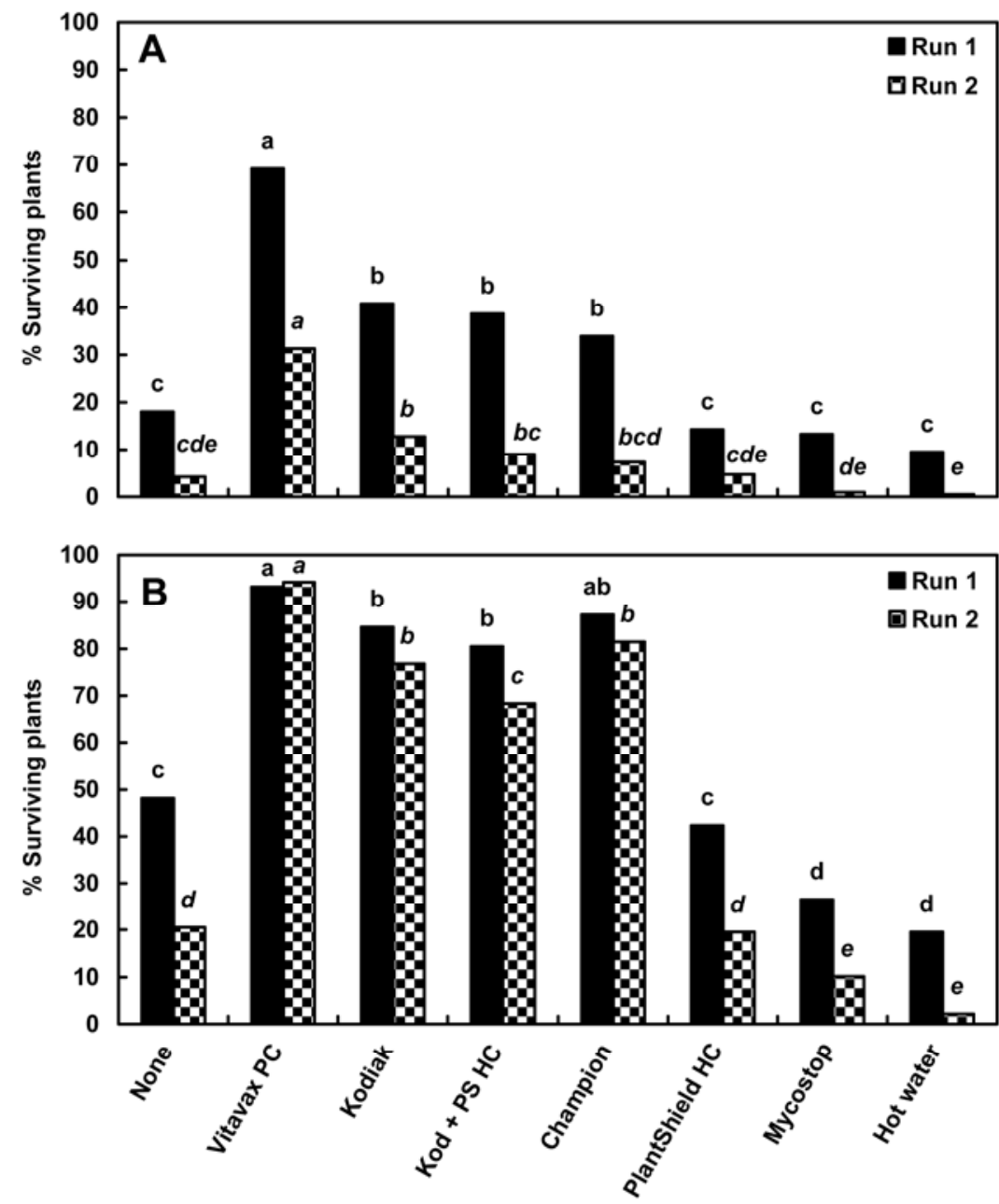

Fig. 3. Mean percent emergence and survival of peanut seedlings 5 weeks after planting in A, natural soil with inoculum of Aspergillus niger added or $\mathbf{B}$, natural soil with no added inoculum. Means are averaged across three peanut lines. Bars with the same letter within a run are not different based on Waller-Duncan procedure with $k$-ratio $=100$.
2008, the highest stand counts were produced by seed treated with Kodiak; these stands were significantly greater than those produced by untreated seeds (Fig. 8).

In 2007, there was much higher incidence of postemergence damping-off than in 2008 (139 postemergence deaths observed in the entire field over the course of the experiment compared to 13 in 2008). In both years, the pathogen most commonly observed on plants exhibiting postemergence damping-off was A. niger. A. niger was observed in $94 \%$ of postemergence deaths in 2007, and $96 \%$ in 2008. In 2007, there was significant effect of peanut line $(P<0.0001)$ and treatment $(P=0.0289)$ on postemergence dampingoff. The highest incidence of postemergence damping-off was observed in Bailey (N03081T) plants. The percentage of the total stand that died after emerging in 2007 averaged $3.5 \%$ in plots of untreated seed 5 weeks after planting. Postemergence damping-off in other treatments ranged from 1.7 to $2.1 \%$. In 2008 , only peanut line affected incidence of postemergence damping-off $(P=0.0194)$. Again, a higher percentage of Bailey (N03081T) plants died than plants from the other two peanut lines.

There was a significant interaction between year, peanut line, and seed treatment for the adjusted data (Table 6). In 2007,

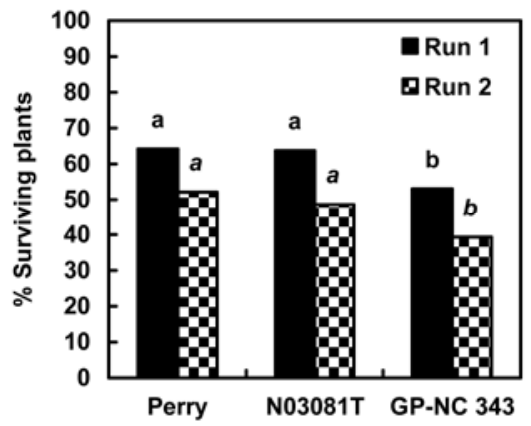

Fig. 4. Mean percent emergence and survival of peanut lines GP-NC 343, Bailey (N03081T), and Perry 5 weeks after planting in the greenhouse in natural soil. Means are averaged across eight seed treatments. Bars with the same letter within a run are not different based on WallerDuncan procedure with $k$-ratio $=100$.

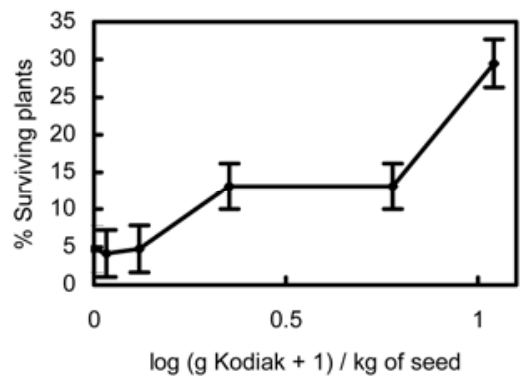

Fig. 5. Effects of Kodiak dose on number of emerged, surviving peanut seedlings 5 weeks after planting in the greenhouse. Bars represent the standard error. 
there were no differences among peanut lines $(P=0.2103$; ANOVA by year not shown), whereas in 2008 plots planted with Perry had a higher adjusted percentage of emerged, surviving plants $(71 \%)$ compared to GP-NC 343 (54\%) and Bailey $(58 \%)$. In these adjusted data, there was a significant interaction between peanut line and seed treatment in both years $(P=$ 0.0004 in $2007, P<0.0001$ in 2008). In adjusted data for all peanut lines, the highest percentage of emerged, surviving plants was found with seeds treated with Kodiak, but only in 2008 was this significantly larger than the percentage of surviving plants from untreated plots $(110.9 \%$ with Kodiak versus $43.8 \%$ from untreated seeds). In both years, none of the other treatments increased the percentage of emerged and surviving plants over untreated seed (data not shown).

\section{DISCUSSION}

To mimic as closely as possible the soil microflora that would be encountered in organic peanut production in North Carolina, a field undergoing transition to organic production was used in the field trial and was the source of soil used in all greenhouse trials. Microplots were managed conventionally. In either case, the pathogens observed in our research could have arisen either from the seeds themselves, from the soil, or from both sources. The observation of fungal infections in the germination tests, which were conducted on sterile sand, is evidence for the presence of seedborne inoculum in these trials. The soilborne fungi Fusarium spp., Pythium spp., Rhizoctonia spp., Rhizopus spp., Trichoderma spp., and A. niger, which were observed in greenhouse experiments, have all been previously associated with peanut seeds and seedling diseases $(6,7,28)$.

In the field, the primary disease observed postemergence was Aspergillus crown rot. Development of Aspergillus crown rot in peanut has been associated with dry weather conditions (33), and a field study with the cultivar Florunner found that $A$. niger was more often associated with shells and kernels in nonirrigated plots compared to irrigated plots (9). In 2007, drought conditions at Lewiston may have contributed to the development of Aspergillus crown rot. Although rainfall was normal in the 2008 microplot experiment, it is possible that reliance on rainfall instead of irrigation may have increased incidence of Aspergillus crown rot compared to 2007. The lack of rotation between years in microplots also may have contributed to increased disease

Table 4. $P$ values from analyses of variance using PROC MIXED for effects of cover, peanut line, seed treatment, year, and replicate on emergence and survival of peanut seed 5 weeks after planting microplots at Clayton, $\mathrm{NC}$

\begin{tabular}{lccc}
\hline Source & df & Counted $^{\mathbf{P}} \boldsymbol{>} \boldsymbol{F}$ & Adjusted $^{\mathbf{z}} \boldsymbol{P} \boldsymbol{F}$ \\
\hline Cover $(\mathrm{C})$ & 4 & 0.0525 & 0.0567 \\
Peanut line (PL) & 2 & 0.3358 & 0.5916 \\
Treatment (T) & 4 & 0.0526 & 0.0220 \\
PL $\times$ T & 8 & 0.8391 & 0.9521 \\
$\mathrm{C} \times$ PL & 8 & 0.9736 & 0.9833 \\
$\mathrm{C} \times \mathrm{T}$ & 16 & 0.2163 & 0.2307 \\
$\mathrm{C} \times$ PL $\times$ T & 32 & 0.8462 & 0.7560 \\
Year $($ YR & 1 & 0.7246 & 0.1711 \\
Replicate $($ YR & 6 & 0.4242 & 0.1038 \\
Replicate $\times$ C (YR) & 24 & 0.9129 & 0.9746 \\
YR $\times$ PL & 2 & 0.0049 & 0.0461 \\
YR $\times$ T & 4 & 0.3799 & 0.6692 \\
YR $\times$ C & 4 & 0.7724 & 0.8101 \\
YR $\times$ C $\times$ PL & 8 & 0.0420 & 0.0160 \\
YR $\times$ C $\times$ T & 16 & 0.7192 & 0.7108 \\
YR $\times$ PL $\times$ T & 8 & 0.0013 & 0.0015 \\
YR $\times$ C $\times$ PL $\times$ T & 32 & 0.3518 & 0.2334
\end{tabular}

${ }^{\mathrm{y}}$ Results from analyses of percent emergence and survival of counted seedlings.

${ }^{\mathrm{z}}$ Results from analyses of percent emergence and survival using data adjusted to account for maximum percent germination from germination tests. incidence as has been previously reported (28).

In most experiments, seed source and peanut line effects were confounded, making it difficult to draw clear conclusions about potential differences among lines in seedling disease resistance. However, seed source had a much greater impact on germination than peanut line in these trials. Seed quality can be affected by growing and storage conditions, and by mechanical injuries that occur at digging, combining, curing, storage, and shelling (36). Germination of Perry seed in 2008 and one source of GP-NC 343 seed used in 2007 was much lower than commercially acceptable. The Perry seed was obtained from a commercial sheller but would not have been sold to growers. A severe drought in 2007 may have contributed to poor seed quality in Perry in 2008. All other seed used in 2008 was produced under irrigation in 2007. The GP-NC 343 seed used in the 2007 field and microplot trials had been over-dried after harvest, which may have reduced germination.

Seed from breeder or research sources was generally of very high quality. Reducing mechanical injury from shelling decreases the severity of fungal infections (7). Bell (8) demonstrated that uninjured, untreated peanut seeds had higher emergence and were less susceptible to infection by a variety of seed pathogens than untreated seed that had been mechanically injured. Likewise, seeds that had been sorted to remove broken, shriveled, or discolored seeds exhibited higher emergence and decreased plant mortality compared to unsorted seeds (39). In our studies, breeder seeds had fewer mechanical injuries and more seed had intact coats than is typically observed in commercially available seeds.

In experiments where seeds of all three peanut lines were obtained from a single source, as in the greenhouse inoculation experiments, differences in emergence and survival would have been evidence of differences in the characteristics and germination speed of the different peanut lines. However, there were no differences in the response of the three peanut lines to inoculation with A. niger in the greenhouse, and other differences were inconsistent across experiments. In the field, incidence of

Table 5. Effects of cultivar and cover crop on mean percent emergence and survival of peanut seedlings 5 weeks after planting in microplots at Clayton, NC

\begin{tabular}{|c|c|c|c|c|c|c|}
\hline \multirow[b]{2}{*}{ Cover } & \multicolumn{2}{|c|}{ Perry } & \multicolumn{2}{|c|}{ Bailey } & \multicolumn{2}{|c|}{ GP-NC 343} \\
\hline & 2007 & 2008 & 2007 & 2008 & 2007 & 2008 \\
\hline None + Muscodor & $54.5 \mathrm{a}^{\mathrm{z}}$ & $49.5 \mathrm{~b}$ & $85.0 \mathrm{a}$ & $52.5 \mathrm{~b}$ & $38.5 \mathrm{~b}$ & $64.0 \mathrm{a}$ \\
\hline None & $57.0 \mathrm{a}$ & $59.5 \mathrm{ab}$ & $91.0 \mathrm{a}$ & $66.0 \mathrm{a}$ & $58.0 \mathrm{a}$ & $61.0 \mathrm{a}$ \\
\hline Oat & $54.5 \mathrm{a}$ & $53.0 \mathrm{ab}$ & $90.5 \mathrm{a}$ & $66.5 \mathrm{a}$ & $52.5 \mathrm{a}$ & $58.5 \mathrm{a}$ \\
\hline Triticale & $56.0 \mathrm{a}$ & $63.0 \mathrm{a}$ & $89.0 \mathrm{a}$ & $67.5 \mathrm{a}$ & $56.0 \mathrm{a}$ & $61.5 \mathrm{a}$ \\
\hline Wheat & $53.0 \mathrm{a}$ & $57.5 \mathrm{ab}$ & $87.0 \mathrm{a}$ & $74.0 \mathrm{a}$ & $52.5 \mathrm{a}$ & $61.0 \mathrm{a}$ \\
\hline Mean & 55.0 & 56.5 & 88.5 & 65.3 & 51.5 & 61.2 \\
\hline
\end{tabular}

${ }^{\mathrm{z}}$ Means in a column with the same letter are not different based on Waller-Duncan procedure with $k$-ratio $=100$. Means cannot be compared across years or cultivars. 
Aspergillus crown rot was higher on Bailey than on Perry or GP-NC 343. This difference may reflect the higher populations of this line or differences in disease resistance between peanut lines. Further evaluation of peanut lines for seedling disease resistance is desirable, but breeding for resistance could be problematic because of the large numbers of seeds needed for screening. Seed generally are very limited in number in early generations of peanut selection.

Regardless of peanut line, the commercial B. subtilis seed treatment, Kodiak, significantly increased the percent emergence and survival of peanut seedlings compared to untreated seeds in many of our trials, and in several cases was not
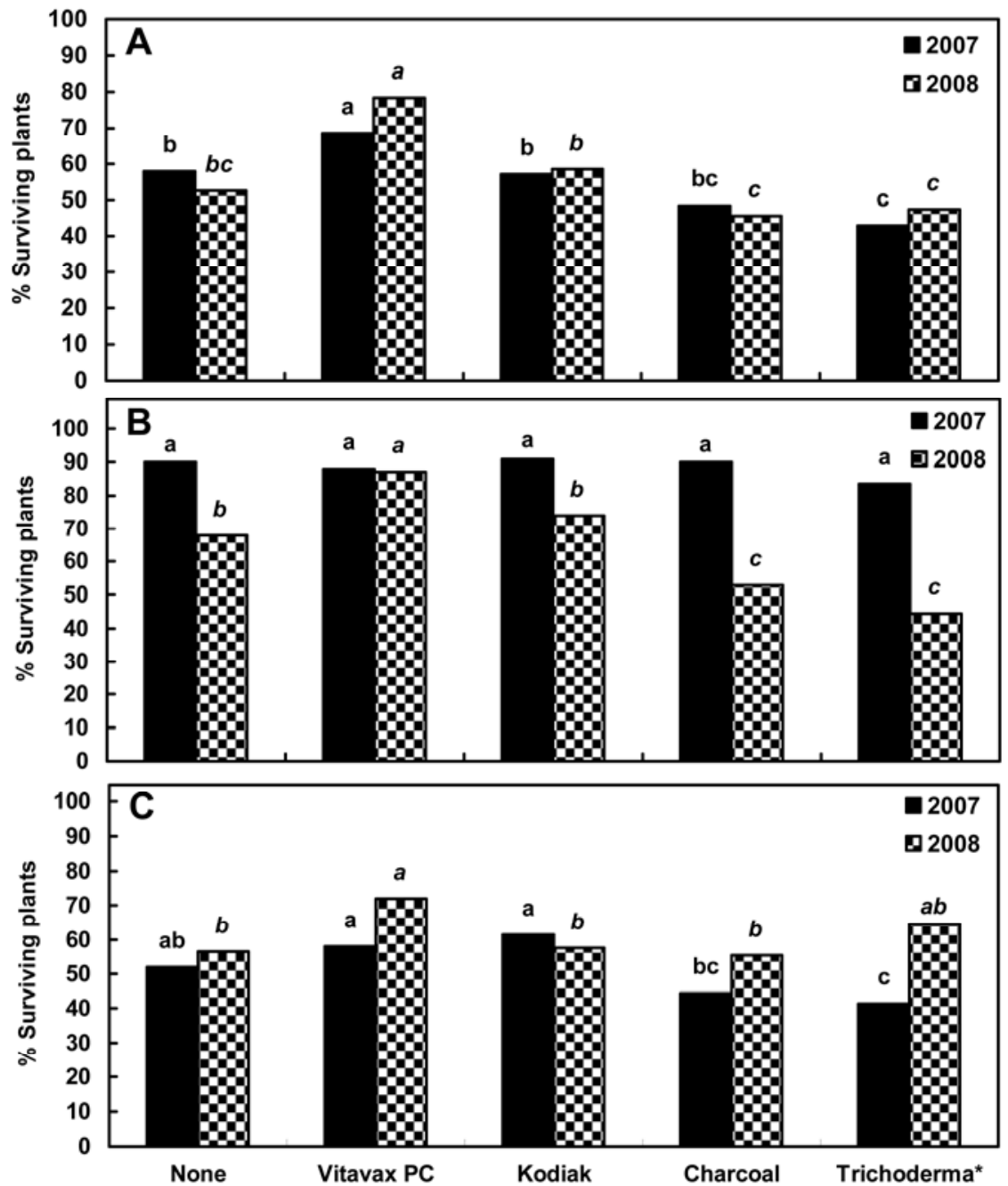

Fig. 6. Mean percent emergence and survival of peanut seedlings in microplots at Clayton, NC, 5 weeks after planting of the peanut lines A, Perry; B, Bailey (N03081T); and C, GP-NC 343. Bars with the same letter within years are not different based on Waller-Duncan procedure with $k$-ratio $=100$. Asterisk indicates differences in formulation of Trichoderma harzianum. In 2007, T-22 Planter Box was used; in 2008, Plantshield HC.

Table 6. $P$ values from analyses of variance using PROC MIXED for effects of peanut line, seed treatment, year, and replicate on emergence and survival of peanut seed 5 weeks after planting in the field in Lewiston, $\mathrm{NC}$

\begin{tabular}{lccc}
\hline Source & df & Counted $^{\mathbf{y}} \boldsymbol{P} \boldsymbol{F}$ & Adjusted $^{\mathbf{z}} \boldsymbol{P}>\boldsymbol{F}$ \\
\hline Peanut line (PL) & 2 & 0.3492 & 0.7653 \\
Treatment (T) & 3 & 0.3767 & 0.3833 \\
PL $\times$ T & 6 & 0.2487 & 0.3542 \\
Year (YR) & 1 & 0.4921 & 0.3984 \\
Replicate (YR) & 6 & 0.0006 & 0.0005 \\
YR $\times$ PL & 2 & 0.0007 & 0.5338 \\
YR $\times$ T & 3 & 0.0009 & 0.0499 \\
YR $\times$ PL $\times$ T & 6 & 0.2182 & 0.0001 \\
\hline
\end{tabular}

${ }^{\mathrm{y}}$ Results from analyses of percent emergence and survival of counted seedlings.

${ }^{\mathrm{z}}$ Results from analyses of percent emergence and survival using data adjusted to account for maximum percent germination from germination tests.

significantly different from the standard fungicide treatment Vitavax PC. Seed treatment with Kodiak also was effective in one of two field trials. In a field study in Alabama and Georgia, B. subtilis applied in combination with chemical fungicides increased yield over the fungicide alone under poor rotations or moisture stress. Only small effects were found under other more favorable conditions (40).

In the greenhouse trials, copper hydroxide, applied as Champion WP, significantly increased percent emergence and survival of seedlings grown in natural soil, but results were not consistent in infestation trials. Copper hydroxide treatment may provide an alternative to conventional chemical seed treatment fungicides in organic production, where it would pose less of a contamination risk to the environment than copper applied to foliage for leaf spot control (12).

Treatment with $M$. albus at planting did not control seedling disease and sometimes suppressed emergence. It would be preferable to apply $M$. albus before planting, similar to the timing used for fumigation of conventional peanut fields with metam sodium (24). In our studies, and in peanut production generally, it would have been impractical to apply the rye grain formulation of $M$. albus as a preplant treatment due to equipment limitations. We therefore applied the organism at the time of planting, which may have decreased emergence through direct inhibition of seed germination. In the microplots, where a lower rate of M. albus was used in 2008 than in 2007, the inhibitory effect on peanut seedlings was still observed. In other studies, $M$. albus used as a preplant "mycofumigant" stunted eggplant and sugar beet plants
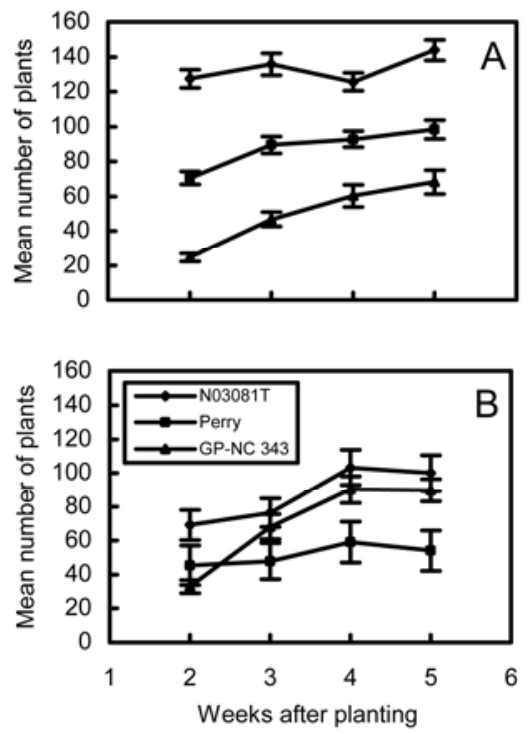

Fig. 7. Weekly mean stand counts of the three peanut lines GP-NC 343, Bailey (N03081T), and Perry for 5 weeks after planting in Lewiston, NC, in A, 2007 and B, 2008. Means are averaged across four seed or soil treatments. Bars represent the standard error. 
(37). Development of a liquid suspension of $M$. albus for use as a preplant treatment could provide an organic alternative to the low rates of metam sodium currently used in conventional peanut production.

Most of the treatments we tested did not increase seedling emergence and survival over untreated checks, and a few treatments appeared to be inhibitory to emergence and survival. T. harzianum treatments did not increase emergence, in contrast to previous studies (14,30). Soil amendment with Monarda also was not effective. Monarda herbage has been found to be phytotoxic to poinsettia and impatiens (K. D. Gwinn, personal communication). In the greenhouse, treatment of virginia-type peanuts with Mycostop resulted in extremely low emergence. S. griseoviridis, the biological agent in Mycostop, may not be able to successfully colonize peanut roots. This organism has been shown to have variable ability to colonize roots depending on the plant host (29).

Planting peanuts after small grain cover crops did not affect emergence and survival and did not interact with seed treatments. Crop residue was tilled into the soil prior to planting because studies to date have indicated that intensive tillage is required for weed management in organic peanut production (23). Results could be different in reduced or no-till systems.

In general, when data were adjusted for germination of individual seed lots, results and interpretation did not differ from those obtained with unadjusted seedling counts. Results were often inconsistent between runs and years, which is not uncommon in biocontrol studies with these organisms $(4,5,15)$. However, despite inconsistencies among other treatments, seed treatment with Kodiak was often effective, allowing us to conclude that it is a possible alternative to standard chemical fungicides in peanut stand establishment.

We used Kodiak at a rate much higher $(10 \mathrm{~g} / \mathrm{kg}$ seed in the greenhouse and 2.5 $\mathrm{g} / \mathrm{kg}$ seed in the microplot and field) than

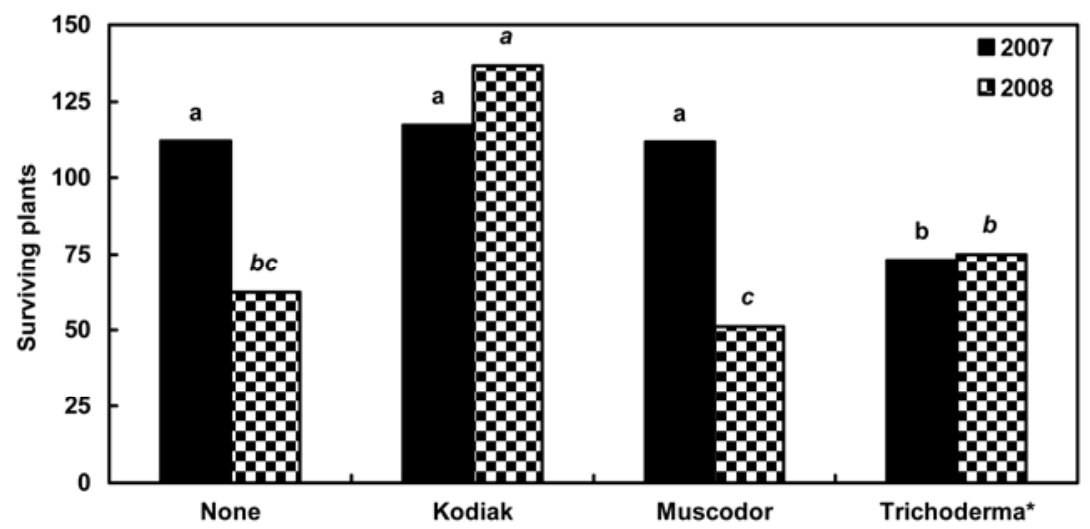

Fig. 8. Mean stand counts of peanut planted with seed or soil treatments at 5 weeks after planting in Lewiston, NC. Means are averaged across three peanut lines. Bars with the same letter are not different based on Waller-Duncan procedure with $k$-ratio $=100$. Asterisk indicates differences in formulation of Trichoderma harzianum. In 2007, T-22 Planter Box was used; in 2008, Plantshield HC. the current label rate. At the labeled rate of $0.08 \mathrm{~g} / \mathrm{kg}$ seed, Kodiak is intended to be used in combination with standard chemical fungicides. At the labeled rate, there would be approximately $4.3 \times 10^{9}$ viable spores per $\mathrm{kg}$ of seed, while at the rate we used in the greenhouse there were $5.4 \times$ $10^{11}$, and in the microplots and field 13.75 $\times 10^{10}$ spores per $\mathrm{kg}$ of seed. We observed a greater percentage of emergence and survival in the greenhouse with rates higher than the labeled rate. A new formulation or a change in the labeled rate would allow growers to take advantage of the benefits obtained from treating seed with Kodiak in the absence of a fungicide. Cost of the treatment needs to be competitive with high seeding rates, which currently is the only method growers can use to offset losses due to poor stands.

Due to the confounding effects of seed source and seed line, we cannot make conclusions about specific cultivars based on seedling disease resistance; however, Bailey may be the best option for organic production due to its resistance to other pathogens. Further studies with careful selection of seed lots with similar germination rates could elucidate differences in resistance to seedling pathogens among peanut lines. Currently, the few growers who are attempting production of certifiedorganic peanuts in the Southeast are planting untreated seed at very high seeding rates. We recommend that growers planting untreated seed select high quality seed with a minimum of mechanical injuries. The research presented here indicates that seed treatment protocols using Kodiak or copper hydroxide could provide an option for growers of organic peanuts. Future studies should focus on establishing rates and conditions under which these treatments would be most effective, economical, and environmentally responsible. Further collaboration with industry to establish labels or formulations specific for organic production will also be important in developing options for growers. 
Benson, D. M., Conway, K. E., Rothrock, C. S., Schneider, R. W., Ownley, B. H., Canaday, C. H., Keinath, A. P., Huber, D. M., Sumner, D. R., Motsenbocker, C. E., Thaxton, P. M., Cubeta, M. A., Adams, P. D., Backman, P. A., Fajardo, J., Newman, M. A., and Pereira, R. M. 2001. Viability and stability of biological control agents on cotton and snap bean seeds. Pest Manag. Sci. 57:695-706.

16. Fraternale, D., Giamperi, L., Bucchini, A., Ricci, D., Epifano, F., Burini, G., and Curini, M. 2006. Chemical composition, antifungal and in vitro antioxidant properties of Monarda didyma L. essential oil. J. Essential Oil Res. 18:581-585.

17. Frimpong, A., Nyarko, G., Bayor, H., and Apeliga, J. A. 2004. Effects of different seed treatment methods on the percent germination, seedling vigor, and biomass production of groundnuts in Ghana. Pakistan J. Biol. Sci. 7:1024-1028.

18. Gohel, V., Singh, A., Vimal, M., Ashwini, P., and Chhatpar, H. S. 2006. Bioprospecting and antifungal potential of chitinolytic microorganisms. Afr. J. Biotechnol. 5(2):54-72.

19. Guerena, M., and Adam, K. 2008. Peanuts: Organic Production. H. Michels, ed. Published online by National Sustainable Agriculture Information Service.

20. Gwinn, K. D., Greene, S. E., and Ownley, B. H. 2007. Monarda bioactive herbage reduces Rhizoctonia disease losses in tomato transplants. (Abstr.) Phytopathology 97:S44.

21. Gwinn, K. D., Greene, S. E., Trently, D. J., and Ownley, B. H. 2006. Inhibition of sclerotia of Sclerotinia sclerotiorum by Monarda and its essential oils constituents. (Abstr.) Phytopathology 96:S44.

22. Isleib, T. G., Rice, P. W., Mozingo, R. W., II, Bailey, J. E., Mozingo, R. W., and Pattee, H. E. 2003. Registration of 'Perry' peanut. Crop Sci. 43:739-740.
23. Johnson, W. C., III, and Mullinix, B. G., Jr. 2008. Potential weed management systems for organic peanut production. Peanut Sci. 35:6772 .

24. Jordan, D. L., Spears, J. F., Brandenburg, R. L., Brown, A. B., Shew, B., Roberson, G. T., and Bullen, S. G., eds. 2008. 2008 Peanut Information. N.C. Coop. Ext., Raleigh AG-331.

25. Kannwischer, M. E., and Mitchell, D. J. 1978. The influence of a fungicide on the epidemiology of black shank of tobacco. Phytopathology 68:1760-1765.

26. Kishore, G. K., Pande, S., and Harish, S. 2007. Evaluation of essential oils and their components for broad-spectrum antifungal activity and control of late leaf spot and crown rot diseases in peanut. Plant Dis. 91:375-379.

27. Kloepper, J. W., Ryu, C.-M., and Zhang, S. 2004. Induced systemic resistance and promotion of plant growth by Bacillus spp. Phytopathology 94:1259-1266.

28. Kokalis-Burelle, N., Porter, D. M., RodriguezKabana, R., Smith, D. H., and Subrahmanyamm, P., eds. 1997. Compendium of Peanut Diseases, 2nd ed. American Phytopathological Society, St. Paul, MN.

29. Kortemaa, H., Rita, H., Haahtela, K., and Smolander, A. 1994. Root-colonization ability of antagonistic Streptomyces griseoviridis. Plant Soil 163:77-83.

30. Lashin, S. M., El Nasr, H. I. S., El Nagar, M. A. A., and Nofal, M. A. 1989. Biological control of Aspergillus niger the causal organism of peanut crown rot by Trichoderma harzianum. Ann. Agric. Sci. 34:795-803.

31. Melouk, H. A., and Shokes, F. M. 1995. Peanut Health Management. American Phytopathological Society, St. Paul, MN.

32. Partridge, D. E., Sutton, T. B., and Jordan, D. L. 2006. Effect of environmental factors and pesticides on mycoparasitism of Sclerotinia minor by Coniothyrium minitans. Plant Dis.
90:1407-1412.

33. Pattee, H. E., and Young, C. T., eds. 1982 Peanut Science and Technology. American Peanut Research and Education Society, Yoakum, TX

34. Sailaja, P. R., Podile, A. R., and Reddanna, P. 1998. Biocontrol strain of Bacillus subtilis AF 1 rapidly induces lipoxygenase in groundnut (Arachis hypogaea L.) compared to crown rot pathogen Aspergillus niger. Eur. J. Plant Pathol. 104:125-132.

35. Shew, H. D. 1983. Effects of soil matric potential on infection of tobacco by Phytophthora parasitica var. nicotianae. Phytopathology 73:1160-1163.

36. Spears, J. F., Jordan, D. L., and Bailey, J. E. 2002. A guide for producers of virginia-type peanut seed. In: Peanut Seed Production. Coop. Ext. Serv. Ext. Publ. AG-622. North Carolina State University, Raleigh.

37. Stinson, A. M., Zidack, N. K., Strobel, G. A. and Jacobsen, B. J. 2003. Mycofumigation with Muscodor albus and Muscodor roseus for control of seedling diseases of sugar beet and Verticillium wilt of eggplant. Plant Dis. 87:1349-1354.

38. Strobel, G. 2006. Muscodor albus and its biological promise. J. Ind. Microbiol. Biotechnol. 33:514-522.

39. Tarekegn, G., Sakhuja, P. K., Swart, W. J., and Tamado, T. 2007. Integrated management of groundnut root rot using seed quality and fungicide seed treatment. Int. J. Pest Manag. 53:53-57.

40. Turner, J. T., and Backman, P. A. 1991. Factors relating to peanut yield increases after seed treatment with Bacillus subtilis. Plant Dis. 75:347-353.

41. Wynne, J. C., Beute, M. K., and Nigam, S. N. 1991. Breeding for disease resistance in peanut (arachis-hypogaea 1). Annu. Rev. Phytopathol. 29:279-303. 